\title{
Statsfange i Flensborg 1914
}

\section{af Lorens Filskov}

Købmand Lorens Filskov fra Møgeltønder (1876-1959) blev kaldt landsdelens største humorist. Særlig kendt blev han gennem redaktør Svend Thorsens bog »Lunets senner«.

Ved verdenskrigens udbrud i 1914 blev Filskov arresteret sammen med mange andre danske og slap forst fri efter knap en måneds ophold i Flensborg. Om fængselstiden har han efterladt en dagbog, som her udgives med forklarende indledning.

Preusserne var velforberedte, da der ved starten af 1 . Verdenskrig blev erklæret mobilisering den 1. august 1914. Gennem længere tid havde militære og civile myndigheder truffet forberedelser, så mupålidelige elementer $i$ tilfælde af krig kunne tages i forvaring. Der var opstillet lister over erfarne folk langs kysterne, som havde særlig viden om farvandene, og som i tilfælde af en engelsk flådes opdukken kunne tænkes at ville bistå de fremmede. Også »politisk mistænkelige « folk var sat på lister, så man kunne tage dem i forvaring og derved hindre evt. spionage mod Preussen. Militæret stod bag disse sikkerhedsplaner. De civile centralmyndigheder ønskede derimod at gå så forsigtigt frem som muligt. Alligevel tog de lokale myndigheder ret drastiske skridt, da krigen blev virkelighed.

Den 31. juli gik det løs. I Haderslev, Aabenraa og Sønderborg amter blev en række søfartskyndige folk taget $i$ forvaring - nogle blev sendt til øen Dänholm ved Stralsund, andre blev taget i forvaring i Aabenraa og Sønderborg. Derefter kom turen til de "politisk upålidelige«. En anselig kreds blev arresteret. Fra Haderslev blev de sendt til Dänholm, i Sønderborg amt blev de samlet på slottet, og arrestanter fra Aabenraa, Tønder og Flensborg kom til Altona og Flensborg.

I alt næsten 300 fik statens vågne øje at mærke. De fordelte sig på følgende måde:

\begin{tabular}{lccr}
\hline & \multicolumn{3}{c}{ fangslede august 1914 } \\
\cline { 2 - 4 } amt & søfartskyndige & "politisk upålidelige & i alt \\
\hline Haderslev & 15 & 18 & 33 \\
Aabenraa & 42 & 7 & 49 \\
Sønderborg & 37 & 86 & 123 \\
Tønder & 20 & 54 & 74 \\
Flensborg by & 4 & 7 & 11 \\
\hline i alt & 118 & 172 & 290 \\
\hline
\end{tabular}


Lorens Filskov tegnet i fangslet 1914 af godsinspektor H.C. Davidsen. Gengivet efter Davidsens "Forbryderalbum*, Tonder 1973 s. 25.

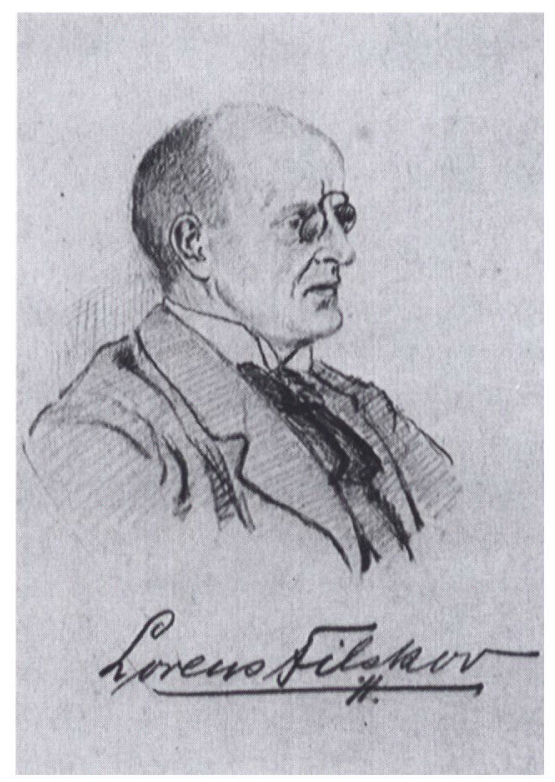

Arrestationerne var foretaget efter påbud fra de militære myndigheder. Den civile statsledelse fandt derimod indgrebet uklogt, og den danske rigsdagsmand H. P. Hanssen vandt hurtigt tilslutning til sit krav om øjeblikkelig frigivelse. Det gjaldt for Preussen om at sikre sig Danmarks neutralitet, og arrestationerne kunne let fremme en antitysk stemning i Danmark. Derfor var statsledelsen enig $i$, at fangerne burde frigives hurtigst muligt - for at skabe sympati $i$ Danmark.

Alligevel varede det længe, før alle var frigivet. Indenrigsministerens krav havde svært ved at trænge igennem de militære myndigheders blokeringer, og H. P. Hanssen måtte intervenere gentagne gange i Berlin, før det lykkedes. Først den 22. september blev de sidste fire løsladt fra navigationsskolen $\mathrm{i}$ Flensborg - dog undtaget lensgreve Schack, som først kom fri den 1. december.

Lorens Filskov fra Tønder var en af de 290 arrestanter. Vi vil nu give ordet til hans dagbog - den tegner billedet af et fængselsophold blandt andre fremtrædende danske i tiden fra 3. august til 12. september 1914.

\section{3. august 1914}

Tidligt om morgenen blev jeg arresteret. Sammen med Th. Thomsen og Davidsen* og under ledsagelse af 2 gendarmer førtes jeg i avtomobil til fængslet $i$ Tønder. Arrestforvarer Callesen tog meget venlig imod os, han anviste os vor

* vedrørende de omtalte personer henvises til navneliste side 124. 
celle og gav os frisk vand og et glas. På cellegangen stiftede vi bekendskab med en "bos", som sad her fordi han havde givet G. fra Højer en "skalle«. Kl. 8 drak vi kaffe i fællesskab. Vi fik (for betaling) rundstykker, smør og honning.

Arrestforvareren gav os ikke just lyse udsigter for fremtiden. Han mente, at vi ligesom 46 andre venner og bekendte fra nabobyerne, som aftenen forud var transporterede til fæstningen i Magdeburg, ville komme til at opholde os $i$ enkeltcelle, og at vi ville komme til at forrette en del arbejde. Mest uhyggelig var det at høre, at vi skulle sidde inden for en 15 meter høj mur $i$ celler, hvor vi gennem et lille hul fik lyset fra oven.

I fængslet her i Tønder findes der 13 celler. I hver celle findes en seng, et bord, en klosetindretning, en kakkelovn og et vaskefad samt en vandkande. Væggene, der er beklædte med gammelt egepanel, bærer mange indskrifter og navne, som for største delen er smukt udskårne med en kniv.

Med årstallet 1848 er der særlig mange navne der tyder på intelligente fanger. Enkelte indskrifter: »Der Wahn ist kurz, die Reue lang. «»Thue Unrecht und scheue das Tageslicht.« "Lerne leiden ohne zu klagen." "Drum Brüder lasset uns reisen - Hoch lebe das Pimrer-Handwerk. « Af årstal fandtes ingen aldre end 1818.

Om middagen fik vi lov til at indtage måltidet $i$ arrestforvarerens stue. Vi fik steg, hvidkål og kartofler og dernæst rødgrød. Om eftermiddagen opholdt vi os $\mathrm{i}$ fængselsgården stadig ventende på ordre til at vi skulle sydpå. Der kom endnu et par mand til fra Tinglev sogn. Aftenen kom, og da der stadig ingen ordre kom til afrejsen, måtte arrestforvareren jo belave sig på at huse os om natten.

Lige mens vi var $\mathrm{i}$ færd med at finde ned i de »bløde dyner«, åbnedes fængselsportene endnu for frøken Bertelsen fra Ballum. (Besøg af [min kone] Dajde). Nægtes kan det ikke, at det var alt andet end indbydende i mørke at kravle ind $\mathrm{i}$ cellen og finde sig til rette $\mathrm{i}$ »bossengen «. Jeg fik tilfældigvis fallesstue med en del andre. Vi kravlede fra den ene seng til den anden for at finde det bedste, og vi reves om "sengetøjet . Næppe havde jeg benene under tæppet, før lopperne (i parentes bemærket min værste plageånd) bed mig af hjertets lyst. Omkring hovedet summede myggene i store skarer. Søvn syntes under disse forhold, hvor lopperne dansede trippevals på ens ben, og myggene i skarer, der ved dagslyset kunne formørke solen, sang serenader ved ørerne, næsten umulig.

Efter at jeg havde fået has på et par lopper og fanget en håndfuld bloddrukne myg, slap jeg alligevel ind. Idet jeg døsede bort, hørte jeg pøbelens sang neden for fængselsgården. "Schleswig - Holstein meerumschlungen« skulle vi endnu 
høre, inden vi gik ind i drømmenes rige. Mine kollegaer snorkede, og jeg sov, - godt forvarede bag de tykke mure og det solide jerngitter for vinduerne.

Kl. 2 vækkedes vi ved, at en arrestant, en ung dansk typograf, blev puttet ind til os, og lidt efter så jeg Th. Johansen fra Terkelsbøl sidde oprejst i sengen rygende på en cigar - han var i kamp med myggene - en håbløs kamp med en "stormagt«. Kl. 6 vågnede vi ved, at bosserne trampede forbi vore celler. Efter at vi havde fået kaffen, lavede Davidsen et skakbræt med figurer af noget gråt papir, som lå $\mathrm{i}$ cellen, og nu begyndte spillet med $\mathrm{Th}$. Thomsen som tilskuer.

Resten af dagen og de næste 3 dage gik med skakspil, kortspil, gymnastik (frk. Bertelsen var leder), diskussion og tobaksrøgning. Vi havde det meget livligt, og enhver var klar over, at fremfor alt måtte humøret holdes oppe. Fra landrådskontoret eller fra politikontoret hørte vi intet. Angående krigen hørte vi meget lidt.

Onsdag aften den 6. aug. fik vi meddelelse om, at vi næste morgen skulle transporteres til generalkommandoen i Flensborg. Denne efterretning glædede os, da vi mente at denne forandring var ensbetydende med frigivelse. Vi var derfor tidlig på færde torsdag morgen. Kaffen fik vi kl. 6, og der blev nu taget den hjerteligste afsked med familien Callesen (fangevogterens). Min kuffert lod jeg stå i Tønder, da jeg antog at være tilbage om aftenen. Under eskorte af en politibetjent og en soldat med ladt gevær samt civilpersoner med revolver i bæltet førtes vi til banegården.

Siddende i en kreaturvogn rullede vi i $31 / 2$ time til Flensborg. Her førtes vi først til politivagten, hvor vi efter en lang ventetid fik besked på, at vi skulle til 2. Landsturms-Batallions-Inspektion (Junkerhulvej). Herfra sendtes vi til et provisorisk millitær-bureau i Nikolajgade, hvorfra vi endelig langt om længe igen bragtes til politivagten, hvor vore navne og fødselsdatoer noteredes, og hvor vore penge blev os fratagne.

Den her fungerende politimand lod os forstå, at vor evtl. frigivelse afhang af, om Danmark holdt sig nevtral (gidsler). Nu forstod vi, at løsladelsen ikke ville ske straks, som det var bleven os sagt $\mathrm{i}$ Tønder, og inden vi ret fik tænkt os om, kørtes vi i fangevogn (salatfadet) (grüner August) til fængslet. Dette var imidlertid optaget, og derfor blev vi anbragte i et temmelig stort værelse $i$ det endnu under opførelse værende nye gymnasium.

Politimanden puttede os her kl. 2 ind og vred nøglen om.

En times tid senere fik vi stegt lever og kartofler og kl. 8 the og brød. Om eftermiddagen fik vi halmknipper og sække stukket ind af døren, og nu gav vi os i lag med at rede vort leje paa gulvet for natten. De 2 kvinder førtes nu hen $i$ et værelse for sig.

Kort efter vor indespærring opdagede vi kendte ansigter $i$ et vindue $i$ en 


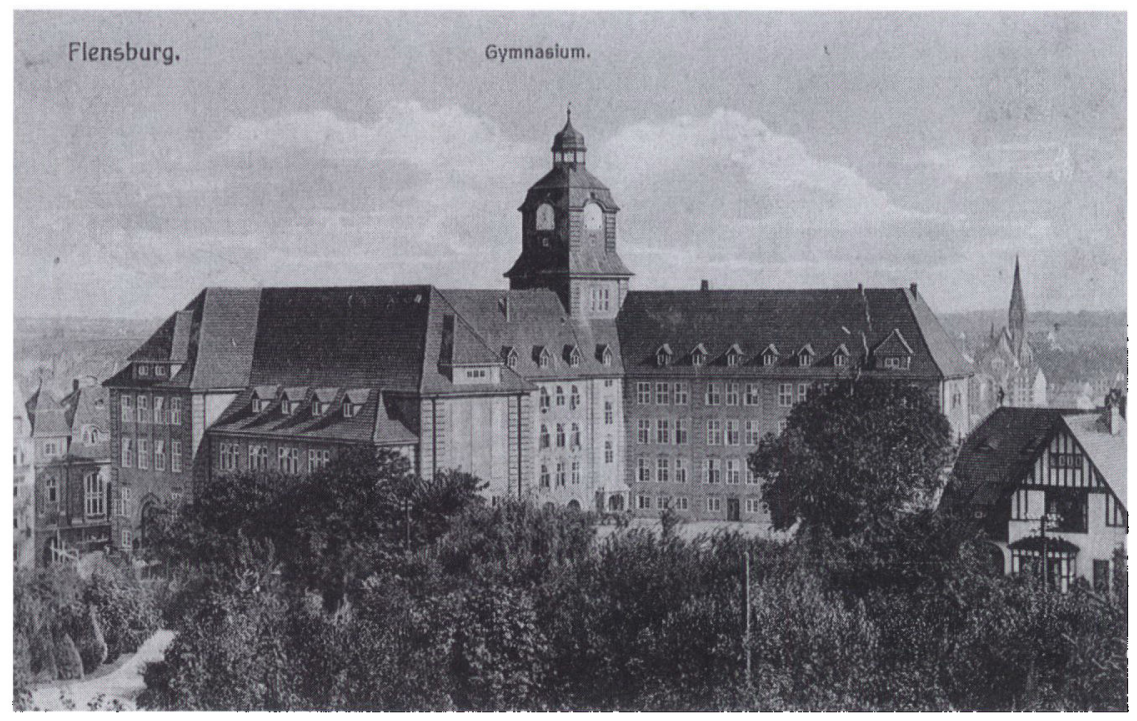

"Altes Gymnasiumi i Flensborg fik nye bygninger i årene 1912-14. Det imponerende skolekompleks var nappe fardigt, da de danske sonderjyder blev indsat her $i$ august 1914. Bygningen blev på den måde indviet af de danske fanger. Skolen er gengivet efter et postkort 1914. Dansk Centralbibliotek for Sydslesvig.

anden fløj af bygningen. Det var hele Flensborg Avis's redaktion samt Andreas Grau. Vi vinkede stilfærdigt til hverandre, og lidt efter bragte politimanden mig 2 bananer fra min broder Tycho. ... Denne lille private "postforbindelse" holdt imidlertid snart op. Intet måtte der leveres fra den ene celle til den anden. Jeg bad om lov til et øjeblik i politiets nærværelse at tale med min broder; men dette blev straks afslået. Nogle cigarer vi havde hos os fra Tønder, røg vi den første eftermiddag, og godt var det, thi den næste dags morgen kom vagten med forbud mod røgning samt imod at åbne vinduerne med undtagelse af de øverste. Nogle officerer, der boede i nærheden, har vistnok lagt mærke til de forsøg, der fra vort vindue blev gjort for at få lidt forbindelse med redaktørerne.

Værst af alt var dog, at vi hverken måtte få aviser eller bøger. Ikke en gang et blad som "Flensburger Nachrichten« måtte vi se. Vi vidste intet og hørte intet, om hvad der foregik ude i Europa, hvor alt stod i brand. Spørgsmål til fangevogteren eller vagtposten besvaredes med hovedrysten.

Tre gange daglig fik vi lov til i 2 hold under vagtpostens ledsagelse at spadsere ned til nødtørftanstalten. Denne tur var vi meget glade for, og selv om vi intet "skulle«, satte i hvert fald én af os sig paa W.C. for på denne måde at hale tiden lidt ud. 
Hos arbejdsfolk, murere og elektrikere, der arbejdede i bygningen, fik vi en gang imellem $i$ forbigående en flygtig meddelelse, der altid lød paa store sejre.

Vi hørte den 7.august, at Belgien var gået imod Tyskland, og at Bryssel var indtaget, hvorved 14.000 belgiere og 7.000 tyskere var faldne. Der fortaltes også, at 2 russiske skibe lå fast i Sønderborg havn, og at svenskerne havde beslaglagt 6 russiske skibe. Alle meddelelser var selvfølgelig meget upålidelige; men alligevel var man glad for selv den mindste nyhed, ja selv med de største løgne vare vi fornøjede, thi det gav dog altid stof til samtale og satte fantasien lidt $i$ bevægelse.

Dagen og dagene gik nu med at se ud af vinduet, snakke, marchere rundt i værelset, spille kort med kort, som vi den første dag, inden bestemmelserne skærpedes, havde fået af værten, der bragte os maden, og som han såvel som politimanden havde glemt at tage fra os.

Vi vogtede over kortene samt over en gammel Familiejournal, som Johansen fra Terkelsbøl havde medbragt, som om det var rene klenodier. Journalen havde vi i Tønder, hvor vi i smug hver eftermiddag læste "Tondernsche Zeitung «, kimset af; men nu skal jeg love for, at den kom til ære og værdighed. Vi læste den bogstavelig talt på kryds og tværs. Redaktørerne, der så at vi ejede en sådan skat, vinkede og gjorde tegn om at låne denne, og efter nogle få dages forløb forbarmede vi os over dem. Nu var det os, der var »bladudgiver« og redaktionen »abonnent«.

Godt var det, at vort værelse var stort, lyst og luftigt. Jeg sad hver eftermiddag nogle timer oppe i vindueskarmen, der vendte mod vest og lod mig beskinne af den dejlige varme sol. Jeg så på skyerne, der som tynde luftige vattæpper drev forbi solen, og jeg så om aftenen solens røde skær i vest, og dens stråler så jeg glitre i utallige skiftende farvetoner på kvistene og i kulørte tagtegl på Duborg-villaernes tage. Jeg så de dejligste roser $\mathrm{i}$ alle farver nede $\mathrm{i}$ villahaverne foran os. Småbørnene legede så muntert, og tjenestepiger i sirlige hvide hovedkapper holdt passiar, jeg var lige ved at falde i søvn i al denne fred og dejlighed, da mine tanker pludselig ved et tilfælde henlededes på vagtpostens tunge trin på korridoren.

Jeg blev med ét lysvågen - hvad var dog det - var det drøm eller virkelighed? Her som fange bag lås og slå med en soldat med ladt gevær ved døren? Jo, det var desværre virkelighed. - Ude i Europa lyste krigsfaklen, og der forestod temmelig sikkert trange og hårde tider for vort land og for vor befolkning. $\mathrm{Nu}$ tog Davidsen og jeg et parti skak.

Om aftenen den 8. aug. så vi en vogn holde i gården. Det var en infanteriofficer, en soldat samt en civilperson, og da de steg af vognen, genkendte vi grev Schack. Vi hørte en rumsteren på gangen, der slæbtes med halm og 
vasketøj, og kort efter var vi klar over, at greven sad bag lås og slå i værelset ved siden af.

Da vi kom til Flensborg, havde vi alle skrevet et kort hjem til familien. Selvfølgelig måtte der kun skrives om private anliggender. Affattelsen skulle være kort og klar, og det tyske sprog burde benyttes. Al korrespondance censureredes af kriminalpolitiet. Nogen anelse om, om brevene kom afsted eller om hvorlænge de lå hos politiet, havde vi ikke.

Efterhånden opdagede vi altid flere kollegaer ved vinduerne. Særlig var det dog på »nødtørftsturene«, der gjordes opdagelser. Vi kiggede gennem dørene, vi kom forbi, når der fejedes ud, og her så vi mange gode bekendte.

Personliste:

Th. Thomsen, Th. Johansen, Davidsen, Sørensen, Jacobsen (Lendemark), Filskov, fru Jessen, frk. Bertelsen.

Christiansen, T. Filskov, Christensen, Vrang, Andr. Grau.

Konsulent Hansen, Hans Petersen, Biehl (Graasten), Steffensen (Flensborg), musikhandler Jacobsen (Flensborg), Bossen (Flensborg), 4 kaptajner (danske), grev Schack og en del andre.

Flere dage havde vi klaget over drikkevandet, der smagte efter asfalt eller tjære; men hertil blev der ligeså lidt taget hensyn til, som at jeg ønskede at tale fængselslægen angående min forstoppelse.

Endelig den 9. aug. måtte én fra hver stue under politiets ledsagelse hente vand ved en offentlig brønd i et anlæg i nærheden. Her var rig lejlighed til at tale med Tycho og de andre lidelsesfæller. Vor politimand var meget skikkelig og lod os drive turen ud så længe som mulig. Vi tog jo kun lidt vand, og når vi var kommen hjem, drak vi af alle livsens kræfter for snart igen at komme ud.

Nu hørte vi af og til noget nyt, og nu blev der hvisket og tisket $i$ alle hjørner. Små sedler og aviser blev puttede fra den ene lomme til den anden i den lavede »trængsel« ved bybrønden.

Davidsen, der er en god blyantstegner, tegnede hver dag en af fangerne $i$ sin lommebog. Begyndelsen var allerede gjort i Tønder, og efterhånden blev bogen til et helt "forbryderalbum«. Fangevogteren fik bogen at se, og han morede sig kostelig. Jeg lavede vittigheder i ret så stor stil, og snart var vi på hat både med politimanden og fangevogteren.

$\mathrm{Nu}$ fik vi oftere lov til under »nødtørftsturene« og vandturene at gøre små svinkeærinder. Vi udpønsede de utroligste ting, som kunne lånes hos kollegaer. Davidsen fik lov til at tale med greven i $1 / 2$ times tid, og Th. Thomsen var $i$ flere timer sammen med Ingeborg i et særligt værelse.

Vor frigivelse, som vi hver dag lige siden arrestationen havde håbet på, lod 
vente på sig. Vi kom i forhør for en krigsret (krigsretsråd Rissern), hvor alt blev nedskreven angående vor stilling i hjemmet. Jeg blev adspurgt, om jeg var medlem af de danske nationale foreninger, og om jeg evtl. var formand for en politisk forening, og om jeg $i$ en fremtrædende grad tog del i den politiske agitation. Akterne skulle vistnok sendes til prøvelse hos landråden $i$ Tønder og måske derfra videre til amtsforstanderen i den by, man var fra.

I dag (den 10.aug.) havde jeg besøg af Dajde. Vi fik lov til at være sammen $i$ et værelse uden politiets nærværelse. Nu hørte jeg en del nyt hjemmefra, til eksempel at der var bleven gjort husundersøgelse hos grev Schack, hvor hele landeværnsarkivet var slæbt bort. En del forretningssager blev nu ordnet, og efter at Dajde var rejst, fik jeg fra byen bragt en kurv med brød, smør og frugt, som var mig meget kærkommen. Besøget var en glædelig oplevelse for mig.

Om eftermiddagen fik Th. Thomsen og jeg af vogteren lov til at tale med grev Schack i $10 \mathrm{~min}$.

Den 11. aug. fik vi en fange til på vor stue, det var landmand $P$. Toft fra Emmerlev, som på grund af sin søns bortrejse til Esbjerg var bleven arresteret søndag aften den 9. aug.

Vi lavede nu en lille revolution mod værten, der fra "Hotel Duborg« bragte os maden. Han udnyttede os nemlig som malkeko. Mk. 3,50 for en sådan forplejning, som vi fik, var der ikke spor af mening i. Maden blev bestilt af, og nu ville vi etablere en sulteskrue eller se at få brød fra byen og så nøjes med almindelig fangekost om middagen. Kommissæren, der kom ind til os for at revidere forhold og kost, sendte os kort efter 2 rugbrød og 4 pølser aldeles gratis. Han syntes dog ikke vi skulle sulte.

Den 12. aug. om morgenen havde vi en stor oplevelse. "Salatfadet« holdt for døren, og ud steg der 17 arrestanter fra Tønder by og kreds. Det var lutter gamle bekendte, der alle havde været arresteret før, det var Skovrøy, Rossen, Andresen, Ludvig Hansen, Møller (Visby), Lorenzen og kone, Brink, Th. Petersen osv.

Vi betragtede os jo allerede som gamle husbeboere, og vi så med overlegenhed på, hvor produkthandler Møller, Rossen og fæller kunne slæbe halm og stoppe madrasser. Nu gik det op for os, at løsladelsen for vort vedkommende lå langt ude i fremtiden. Militærpatroullen på gangen forstærkedes med 3 - 4 mand, og der indrettedes et køkken i huset, hvor vi om morgenen kunne købe kaffe for en rimelig pris. Alt syntes at indrettes på langt sigt - desværre.

Jeg fik hjemmefra en pakke med madvarer, frugt og brev.

Det var jo kun lidet, man fik at vide, da censuren var meget skarp. Mest glad blev jeg ved at høre, at Dajde tog sagen mere rolig end hidindtil.

Den 13. aug. fik vi lov til at læse »Flensburger Nachrichten«, og ad andre 


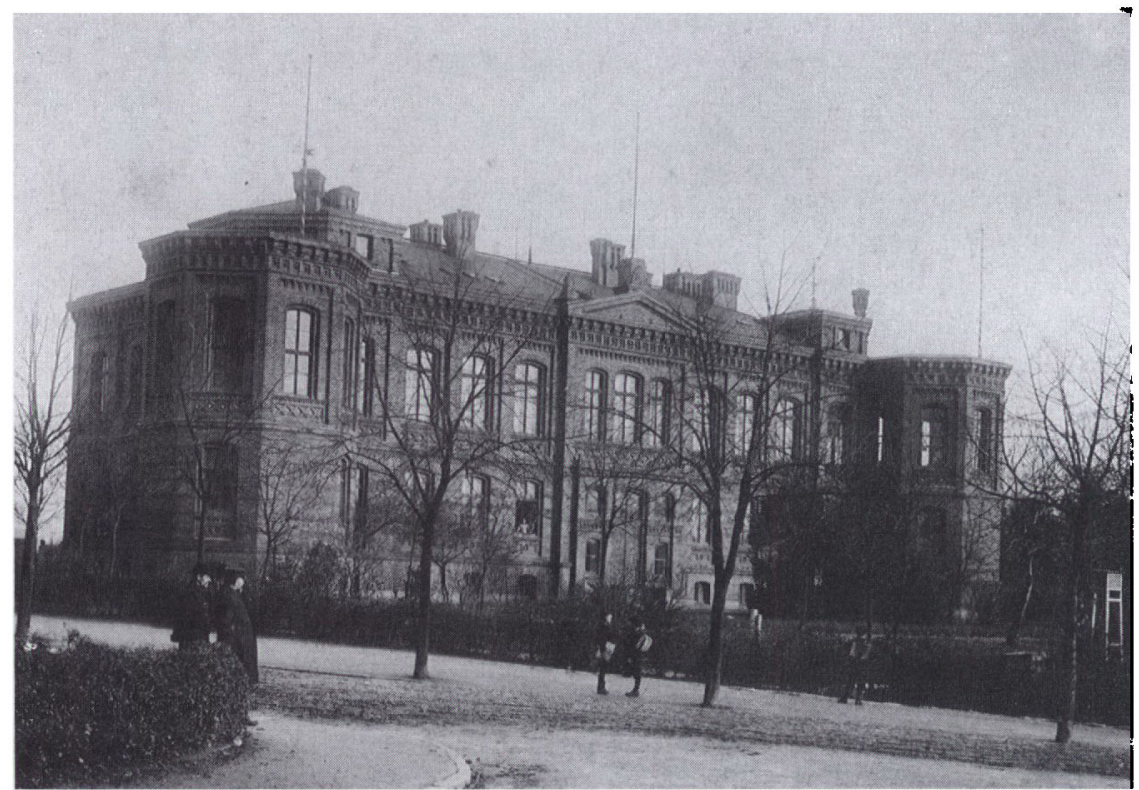

Navigationsskolen pd Munketoft $i$ Flensborg. Her sad de danske sonderjyder arresteret fra sidst $i$ august 1914. Opholdet var dog ganske behageligt. Thorvald Petersen skriver $i$ sine erindringer „Fra Als til Tonder" (1952): "Pd navigationsskolen var tilvarelsen ret fri, vi kunne bevage os efter onske inden for skolepladsens rammer. Hans Brink fra Rorkar gav os gymnastikundervisning, godsinspektor Davidsen tegnede os hver isar, og en dag lod vi os allesammen fotografere nede i skolegården til minde om denne oplevelse." Fotografi af Th. Thomsen o. 1910 i Stadtarchiv Flensburg.

veje fik vi nu en hel del blade hver dag. Store nyheder forefaldt der just ikke ude i verden. Dagen bragte en ret stor begivenhed, nemlig at »redaktionen« fra nu af udgav en dagsavis, kaldet "Flensborg Arrestavis«. Abonnementsprisen fastsattes til 1 cigar daglig, som hver stue havde at erlægge hos "redaktionen « hver morgen. Hver stue fik en medarbejder. Jeg blev korrespondent for stue 306, og Davidsen blev arresttegner, medens Skovrøy blev censor. Først udkomne nummer, som oplæstes i dag af Andr. Grau, vakte stormende munterhed. Dagen gik med besøg på de andre stuer samt med læsning og snak.

Om den 14. aug. er der intet uden det at melde, at vi fik en kollega til på stuen, nemlig Adolf Sørensen fra Byvang.

Dagen efter fik vi lavet et gymnastikhold, og deltagerne heri mødte nu hver morgen på stue 208 for under Hans Brinks ledelse at øve musklerne i en times tid. Arrestavisen, der med undtagelse af søndagen udkom hver dag, var stadig anledning til adspredelse og fornøjelse. „Flensburger Nachrichten«, som nu bragtes os hver eftermiddag, var der ikke meget nyt i. Samtlige danske blade i Nordslesvig var af myndighederne standsede. 
Th. Thomsen og jeg gik som oftest om aftenen sammen med Schack og Skovrøy. Her drøftedes stillingen og fremtidsudsigterne ret indgående.

Om den 15., 16., 17., 18. aug. er der intet særligt at melde. Den 17. fik jeg besøg af [min søn] Johannes, som bragte mig en pakke med frugt, madvarer og linned. Han blev her til den 21. om morgenen, og han sov $i$ byen om natten. Hele dagen var han her hos mig. Dette var mig en glæde, og det morede tilsyneladende Johannes meget at se på hele fængselsindretningen med vagtposter, afløsning etc. Vi var flere gange sammen oppe $\mathrm{i}$ bygningens tårn, det højeste i Flensborg, hvor vi nød den dejligste udsigt.

Den 21. aug. blev der almindelig bestyrtelse i fangselssamfundet. Det rygtedes nemlig, at vi alle skulle transporteres til Rygen eller til et andet fjernt sted. Enkelte af os blev meget nedtrykt over denne meddelelse, og da det blev os sagt, at transporten skulle foregå om aftenen $\mathrm{kl}$. 7, fik alle travlt med forberedelserne til afrejsen. Vi telegraferede hjem til vores resp. koner i Møgeltønder, for at de endnu evtl. kunne få talt med os. Ved middagstid fik vi en ny melding, nemlig den, at vi ikke skulle til Rygen, men til Stade (i Hannover). Dette var selvfølgelig en skuffelse, da vi på Rygen (eller en ø i nærheden) havde udsigt til en del frihed, hvorimod opholdet i Stade for alles vedkommende stod som ret trist. Dagen blev fuld af begivenheder, thi hen på eftermiddagen kom der bud, at transporten herfra foreløbig helt var opgivet. Hvad betød dog alt dette? Nå, man var jo vant til »zik-zak-kurs« - og derfor tog man sagen med ro.

Sent på aftenen skulle vi endnu have en stor, og denne gang glædelig, nyhed. Fru Jessen bragte os nemlig bud fra H. P. Hanssen, at vor frigivelse var nær forestående. Endvidere hørte vi, at den danske presse igen måtte udkomme, og at de andre nordslesvigske arrestanter fra Rygen og Altona allerede var på hjemtur. Vi vidste nu næsten ikke, hvad vi skulle tro; men for ikke at udsætte os for en stor skuffelse, modtog vi budskabet med megen skepsis.

Den 22. aug. blev en dag fuld af alle slags forvirrede og modsigende rygter. Søndag den 23. fik vi besøg af konerne samt af venner og bekendte. Dajde var allerede kommen lørdag middag, og hun blev til søndag aften kl. 8 .

Efter alt at dømme måtte løsladelsen ske om mandagen; men den som havde været skeptiker var på den rigtige side, thi mandag middag holdt der en stor pakvogn for døren, og nu fik vi ordre til at holde os selv rede til udrykning kl. 2. Vi skulle nu flyttes hen på den gamle navigationsskole. Pakvognen fik sengetøjet og vores kufferter med, og ved den fastsatte tid karmedes (kørtes) vi nu i lukket char a-banc i 4 læs til vort nye hjem. Overborgmester Dr. Todsen havde beordret et sådant køretøj, da han ikke ønskede os i en almindelig fangevogn, som vi jo forresten havde stiftet bekendtskab med.

På navigationsskolen kom vi 13 til 15 mand på hver stue.

Den første dag blev vi lukkede inde her og fik temmelig strenge forskrifter, 


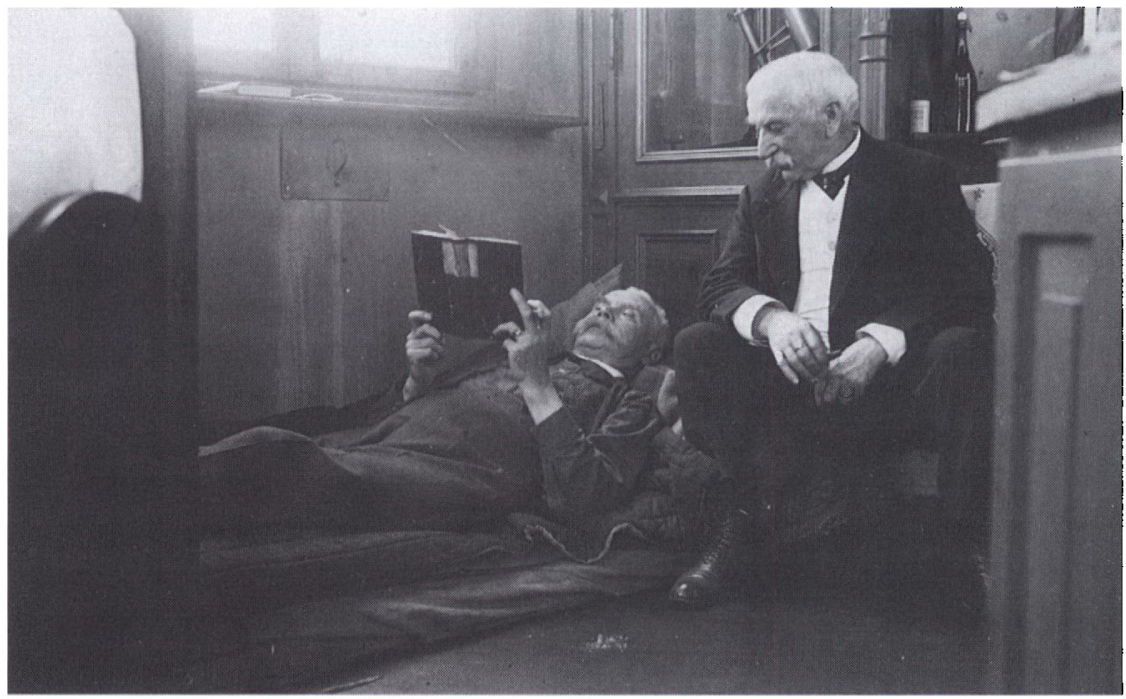

En rolig stund i Navigationsskolen - P. Skovroy laser liggende på en rullemadras, mens Lorens Poulsen ser til. Foto $i$ O.D. Schacks arkiv $i$ landsarkivet.

men om tirsdagen fik vi lov til at spadsere en times tid $(2-3+)$ i skolens indelukkede gård. Opholdet her var iøvrigt ret behageligt.

Aviserne bragte af og til meldinger om nye tyske sejre. Da vi den 25 . om aftenen kl. 9 var gået til ro, begyndte alle byens kirkeklokker at ringe, og det rygtedes snart, at den belgiske fæstning Namur nu også, kun 16 dage efter Liège, var falden for de tyske våben. Russerne havde haft nogen fremgang ved Gumbinnen; men ellers hørte vi kun om nederlag for Frankrig og Rusland og om glimrende sejre for Tyskland.

Om aftenen (den 25. aug.) kom alle vi fra Tønder amt i forhør hos en politimand. Vi kom for enkeltvis, og enhver blev spurgt om han var dansksindet, som selvfølgelig blev besvaret med ja. Et dumt spørgsmål, skulle man synes, da vort danske sindelag jo dog nærmest var årsagen til arrestationen.

Den 26. aug. fik jeg gennem min svigerinde (Tychos kone) en meget trist meddelelse. Lille Ove [sønnen] var styrtet af cyklen sammen med Johannes, og han havde forslået hovedet slemt. Johanne og Dajde havde skiftevis våget hos ham om natten. Jeg blev meget urolig ved denne melding og bad vagten henvende sig til politiforvaltningen, for at jeg evtl. kunne få lov til at tage hjem for at høre, hvorledes det gik min dreng. Hjem kunne jeg ikke komme, det tillodes ikke; men politiet telefonerede og fik det svar, at der ingen overhæn- 


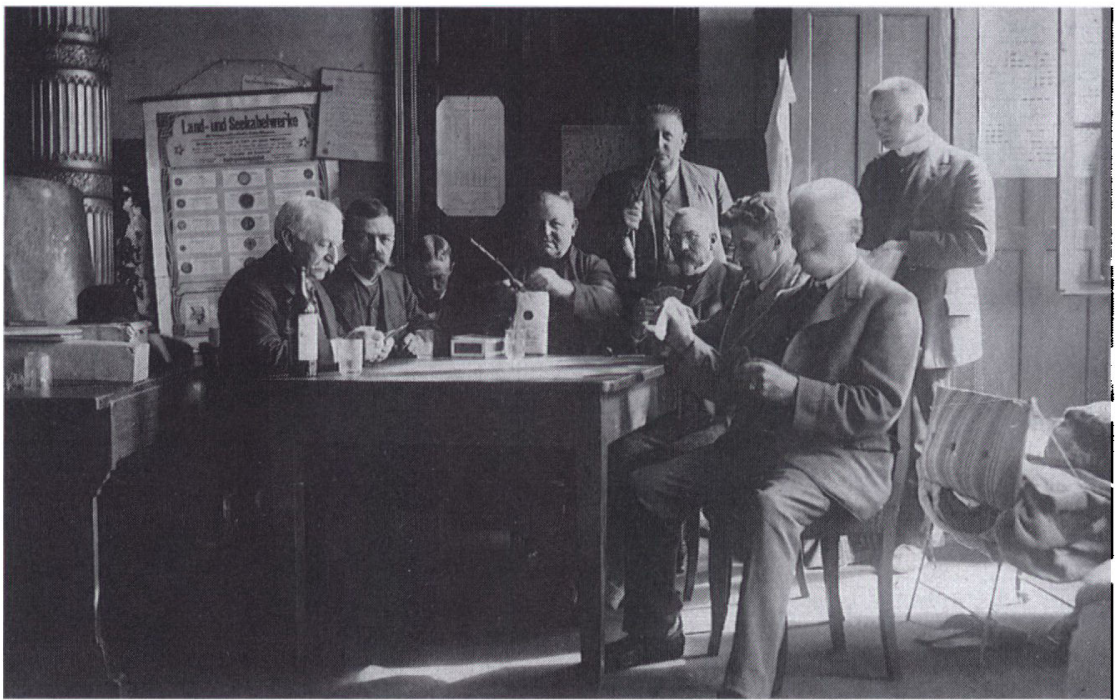

Fangerne spiller kort i Navigationsskolen i Flensborg, september 1914. Fra venstre Lorens Poulsen og H.C. Davidsen. Stående med pibe Adolf Serensen, derefter siddende R.P. Rossen, O.D. Schack og P. Skovroy. Foto i O.D. Schacks arkiv i landsarkivet.

gende livsfare var. Næste dag fik jeg besøg af min kommis Juhler, og jeg blev meget glad ved at høre, at Ove nu havde det meget bedre.

Denne dags eftermiddag løslodes 4 kaptajner, som havde siddet sammen med os siden begyndelsen. Den ene dag gik ellers nu ligesom den anden, og det kan ikke nægtes, at det nu begyndte at blive lidt trivielt. Næste dags middag fik vi besøg af andenborgmesterens stedfortræder, assessor Haupt, der på en meget høflig måde spurgte om vort befindede. Jeg fik - med en maddrøftelse som indledning - lejlighed til at omtale vor fangsling, og jeg spurgte assessoren, om det da ikke beroede på en misforståelse med arrestationen, og jeg understregede de danske nordslesvigeres lovlydighed og loyalitet og beklagede mig over, at vi alle her skulle sidde uvirksomme i så lang tid, bortrevne fra fra kone, børn og forretning.

Angående maden sagde Haupt, at vi skulle have middagsmad hver dag, og da jeg trykkede mig ved selv at betale, lovede han at sørge derfor. Jeg og 6 kollegaer havde helt siden arrestationen levet ved brød med pålæg, samt mælk og kaffe. Den største del af fangerne fik hver dag middagsmad for egne penge bragt fra et hotel. Om fængslingen udtalte Dr. Haupt sig omtrent således: "Jeg er absolut ingen danskerhader og har slet intet imod, at I holder på det danske sprog, og at I har interesse for dansk kultur og litteratur; men I foretager jer 
noget derudover, I arbejder for Nordslesvigs løsrivelse fra det tyske statslegeme. ... Ja, det nytter ikke, De nægter, thi jeg ved det aldeles bestemt. - Tak, aresord giver vi tyskere ikke meget for i denne tid. Vi har i så henseende haft meget dårlige erfaringer, sidst med storfyrsten i Rusland og også med Japan. Jeg forstår godt, at det ikke er behageligt at være indespærret her; men det er vi tyskeres pligt af hensyn til sikkerheden, og De vil næppe slippe ud, før at de urolige tilstande er forbi. Forhåbentligt varer det nu ikke så længe, thi Belgien er jo allerede tysk og bliver tysk, og Frankrig er omtrent maset. Rusland ler vi kun af, de har i grunden nok med sig selv; glæd Dem kun hver dag, når De hører om tyske sejre, thi så snart vi har vore fjender tæmmede, og krigen er til ende, kan De vente frigivelsen«. ...

Så sejerssikker var politichef Dr. Haupt den 28. aug., og jeg må tilstå, at tyskerne absolut havde gode chancer. Hver dag hørte vi om større eller mindre sejre, og den tyske hær var allerede efter at have søndret 2 fæstninger godt på vej til Paris.

Den 29. aug. fik vi lov til at øve gymnastik i gården, og dernæst måtte vi i små kolonner under fangevogterens ledsagelse gå med til byen for at få bad $\mathrm{i}$ "Volksbad «.

Den 30. og 31. aug. udveksledes et par telegrammer mellem os og rigsdagsmand H. P. Hanssen, der dagen forud var rejst til Berlin for gennem de højeste instanser at udvirke vor løsladelse. Fra Erzberger modtog »Flensborg Avis« et telegram, hvori der bl.a. stod: »Efter anmodning af den ny overpræsident skal alle nordslesvigere, som findes i sikkerhedsarrest, løslades.» Vi var imidlertid alle vante til skuffelser, og selv om vi så en sådan meddelelse på prent, ventede vi ikke, at frigivelsen ville gå så glat, thi vi mærkede tydeligt, at de hjemlige og særlig stedlige embedsmænd, bistået af Hahn, Strackerjan og fæller nødig ville slippe os. Det var dem nu, medens forfatningen var sat ud af kraft, en ren svir at få has på alle de såkaldte wagitatorer«.

Dagene gik. - Heldigvis var sundheden god, og appetitten storartet.

Den 2. sept. (Sedandagen) fik vi at vide, at tyskerne stod uden for Paris, og at pariserne forlod byen $\mathrm{i}$ sydlig retning. Hovedstaden var fuldstændig isoleret fra det nordlige Frankrig. Et par dage før havde bladene meldt, at tyskerne i Østprøjsen havde fanget 70.000 mand og jaget resten af russerne på flugt og ud af landet. Til langt ud på natten hørte man jubelen på gaden, og rundt omkring byen på høje og skrænter brændte blussene under tonerne til $» D i e$ Wacht am Rhein«.

Den 4. sept. fik vi besøg af $H$. P. Hanssen. Vi samledes alle med ham i et værelse, og her fortalte han os om det arbejde, han havde gjort for os i Berlin. Han undrede sig over, at vi sad endnu, men mente at frigivelsen kunne ventes hver dag. I Berlin havde regeringen endnu den 16. aug. ikke haft den 


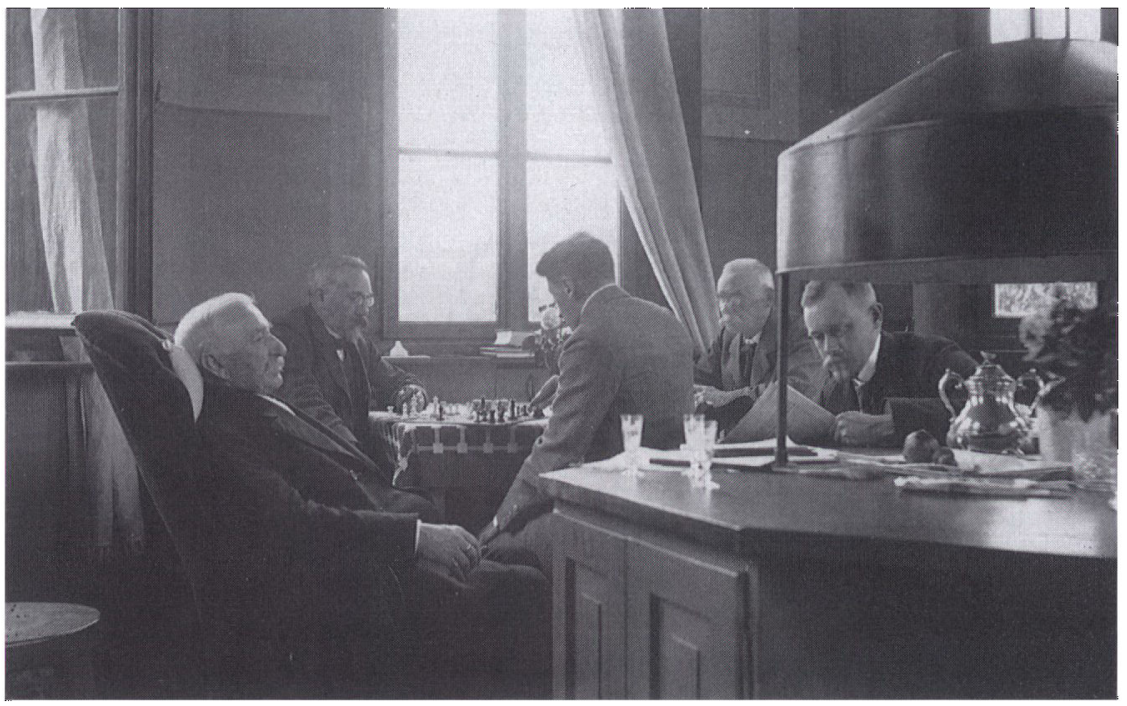

Der spilles skak i Navigationsskolen. Fra venstre Lorens Poulsen, R.P. Rossen, O.D. Schack, P. Skovrøy og H.C. Davidsen. Foto i O.D. Schacks arkiv i landsarkivet.

allermindste anelse om arrestationerne her i Nordslesvig, og den vægrede sig næsten ved at tro Hanssens meddelelser desangående. Dette at overpræsidenten i Slesvig havde undladt at give Berlin underretning havde til følge, at Bülov fratrådte til fordel for Moltke. Hanssen frarådede os at underskrive en tvetydig erklæring, som allerede var blevet forelagt adskillige, og som f. eks. redaktørerne af »Flensborg Avis« allerede havde underskrevet.

Samtlige tyske aviser bragte meddelelser om, at overpræsidenten havde anordnet vor løsladelse, men til trods herfor blev vi siddende. Hver anden dag sendte vi telegrammer, enten til Slesvig eller til generalkommandoen i Altona; men ligenær kom vi.

Den 6. sept. sattes redaktør Christiansen, Simonsen, Christensen og bogholder Wrang på fri fod, og dagen efter slap dyrlæge Ris fra Toftlund ud. Ris havde udstået en skrækkelig behandling i Flensborg politiarrest, inden han kom sammen med os; men herom vil aviserne sikkert berette udførligt senere hen. Samme dag (en søndag) havde jeg besøg af Dajde og lille Ove, de bragte frugt, tøj og madvarer, og da vi hvert øjeblik ventede på løsladelsen, blev de begge her i byen nogle dage for evtl. at følges med mig hjemad.

Torsdag morgen måtte vi imidlertid tage afsked. Et telegram fra borgmester Plevka i Tønder til Rossen lød på: "Bitte noch Geduld« osv.

Biehl og konsulent Hansen fra Graasten slap begge fri om onsdagen, efter at de også havde underskrevet erklæringen, som lyder således: 
»Polizeiverwaltung Flensburg.

Abteilung II

\section{ERKLÄRUNG}

Ich gebe hierdurch die Erklärung ab:

1. Dass ich keine undeutsche Gesinnung bekunden werde.

2. Dass ich nichts betreiben, unterstützen oder begünstigen werde was den deutschen Interessen zuwiederlaufen könnte.

3. Dass ich insbesonders keine Nachrichten über politische oder millitärische Vorgänge verbreiten werde, namentlich nicht über die Landesgrenze hinaus.

4. Dass ich nicht an keinerlei Vereine und Versammlungen dänischer Richtung beteiligen werde.

5. Dass ich meinen Wohnort nur in dringenden Fällen verlassen werde und zwar in keinen Fall ohne daß ich die Polizeibehörde mindestens 24 Stunden vorher über Zweck, Ziel und Dauer der Reise in Kentnis gesetzt und diese sich mit der Reise einverstanden erklärt haben würde.

Eine Abschrift der Verhandlung ist mir behändigt.

\section{(Unterschrift)}

Beglaubigt

Vejret var dejligt varmt hver dag. Vi tilbragte en stor del af dagene med at sidde på en bænk i gården. Hver morgen fra 8-9 gjorde vi gymnastik, og dette bekom os udmærket. Af og til fik vi besøg af Andr. Grau samt af redaktørerne, og altid var der nyheder, som interesserede os $i$ høj grad.

Fredag den 11. sept. fik vi en arrestant til, nemlig gårdejer Ferdinand fra Ladegaardskov ved Graasten. Med ham var vi nu ialt 26 mand og en kvinde (fru Lorenzen fra Ballum).

Lørdag den 12. sept. fik vi besøg af Hoyer fra Trøjborg, der fortalte, at alt hjemme var roligt og stille. Militær lå der næsten ingen af undtagen de soldater, der stod vagt ved baner og broer. Høsten var så at sige bjerget, og alt var gået godt som følge af det fortræffelige vejr i hele 6 uger.

\section{Om udgivelsen}

Lorens Filskovs dagbog er her gengivet $i$ let moderniseret form efter en kopi i Arkivet ved Dansk Centralbibliotek for Sydslesvig, (P 153).

Se også Filskovs arkiv i Landsarkivet i Aabenraa. 


\section{NAVNELISTE}

personer navnt $i$ Lorens Filskovs dagbog

Andresen, A., bankdirektor, Tonder, 1879-1939.

Bertelsen, frøken, Ballum.

Biehl, Carl Chr., bogtrykker, Gråsten, 1872-1950.

Bossen, Jes, rentier, Flensborg.

Brink, Hans, Rørkær, 1888-1918.

Callesen, attestforvarer, Tønder.

Christensen, L.P., redaktionssekretær, Flensborg, 1882-1960.

Christiansen, Ernst, redaktør, Flensborg, 1877-1941.

Davidsen, H.C., godsforvalter, Schackenborg, 1876-1962.

Ferdinand, Johann, gårdejer, Ladegårdskov, Gråsten, 1873-1952.

Filskov, Tycho, redakter, Flensborg, 1885-1950.

Grau, Andreas, redaktør, Flensborg, 1883-1935.

Hansen, Hans, konsulent, Gråsten, 1880-1957.

Hansen, Peter Ludvig, landmand, Abild, 1860-1927.

Jacobsen, Jes, mølleejer, Lendemark, 1870-1949.

Jacobsen, musikhandler, Flensborg.

Jessen, Marie, gift med red. J. Jessen, Flensborg Avis, 1859-1935.

Johansen, Thomas, landmand, Terkelsbel, 1874-1941.

Lorenzen, Hans, lærer, gdr., Ballum, 1862-1956 og hustru Hansigne født Jenssen, 1870-1952.

Møller, Emil, produkthandler, Visby, 1863-1928.

Petersen, Hans, lærer, forsikringsmand, 1865-1937.

Petersen, Thorvald, bagermester, Tønder, 1881-1955.

Riis, Christian Peter Bonniksen, dyrlæge, Toftlund, 1874-1936.

Rossen, R.P., bankdirektør, Tender, 1858-1928.

Schack, Otto Didrik, lensgreve, Schackenborg, 1882-1949.

Simonsen, Peter Chr., redaktør, Flensborg, 1864-1930.

Skovrøy, P.A., redaktør, Tønder, 1851-1935.

Steffensen, Flensborg.

Sarensen, Adolf, gårdejer, Byvang, Emmerlev, 1873-1919.

Thomsen, Thomas, gårdejer, Toghale ved Møgeltønder, 1866-1933.

Toft, Peter, landmand, Emmerlev, 1847-1922.

Vrang, Jørgen, bogholder, Flensborg, 1858-1922.

\section{LITTERATUR OG KILDER}

Karl Alnor: Handbuch zur schleswigschen Frage II. Die Schleswigsche Frage und der Weltkrieg, Neumünster 1926-29, s. 651-705.

Fra H. C. Davidsens «Forbryderalbum«, Tønder 1973.

Tycho Filskov: Seks Aar for Rachel, Tonder u. år, s. 17-52.

H. P. Hanssen: Fra Krigstiden. Dagbogsoptegnelser I, 1924 s. 7-72.

Nis Petersen: Erindringer 1889-1923, manus. i Arkivet ved Dansk Centralbibliotek for Sydslesvig, P 87.

Thorvald Petersen: Fra Als til Tonder. Minder fra udlændighedsảrene, 1952 s. 109-119.

Otto Didrik Schack: Grensesind. Optegnelser fra årene 1913-49, Gyldendal 1970 s. 52-96.

Margrete Schultz: Erindringer fra Tønder 1904-1923, i: Sjy Årb 1987 s. 140-143. 